\title{
'SURELY, GOODNESS AND MERCY SHALL FOLLOW ME...': READING PSALM 23:6 IN CONVERSATION WITH JOHN WESLEY
}

\author{
Ndikho Mtshiselwa \\ Department of Biblical and Ancient Studies \\ University of South Africa \\ mtshivnn@unisa.ac.za
}

\section{ABSTRACT}

On the understanding that the addressees of Psalm 23 experienced the challenges of poverty, corruption, injustices and conflict, the interest of this article lies at asking three cardinal questions: First, what Imago Dei does Ps 23 present in the context of poverty, corruption, injustice and conflict, and more importantly with respect to the 'goodness and mercy' of YHWH? Second, how does the idea of 'goodness and mercy' (cf. Ps 23:6) relate to John Wesley's theology on the 'works of mercy' and 'doing good' - particularly in light of the mission imperatives of the Methodist Church of Southern Africa? Third, how could the Methodist people be the interlocutors of 'goodness and mercy' in South Africa today?

Keywords: Psalm 23; John Wesley; goodness; mercy; poverty; corruption; injustice; conflict.

\section{INTRODUCTION}

The reading of Psalm 23 in conversation with John Wesley presupposes interaction between the biblical text and Methodism, specifically in the South African context. This conversation is enthused by Cone's hermeneutical approach which highlights points of convergence between the biblical text and the context of the modern

\section{UNISA}


readers of the Christian Bible. ${ }^{1} \mathrm{He}$ insists that both the American context and the Christian Bible interpret each other, that is, to the extent that one could possibly not understand one without the other. Although this article draws on Cone's approach, I depart from it in this way: not only will Ps 23 be brought to bear on the South African context, but the bearing of this text on John Wesley's theology on the 'works of mercy' and 'doing good' - particularly in the context of the Methodist Church of Southern Africa (MCSA) and post-apartheid South Africa - will also be brought to light. Based on the literature dealing with Ps 23, John Wesley's theology, the MCSA as well as on the South African context, the discussion will follow the outline below:

- YHWH's' 'goodness and mercy'.

- 'Goodness and mercy’ meets John Wesley.

- Implications of 'goodness and mercy' for the Methodist people.

\section{YHWH'S ‘GOODNESS AND MERCY' - THE IMAGO DEI IN PS 23}

On reading the text of Ps 23 one unavoidably grasps an image of a deity who is defined by 'goodness and mercy' (cf. Ps 23:6). This image exhibits the role that YHWH plays in the entire Psalm. It seems that the goodness and mercy of YHWH alluded to in v.6 presents a summary of the whole Psalm. Thus, it is critical to investigate the Imago Dei in the Psalm under consideration. In definition, the term Imago Dei refers to the image of God that is depicted in the character and works of God. In the text of Ps 23, the imagery of the green pastures (v.2) portrays a God who provides food. With respect to v.3, on the one hand, the idea that the verb 'restores' carries with it the connotation of 'coming back to life', which shows an image of a restorative deity. On the other hand, v.3 also presents a God who leads one in the 'paths/ethical ways' of justice. Furthermore, Ps 23 offers an image of a God who is omnipresent (v.4). That is not all. In v.5, God is portrayed as a servant or a host who prepares a table for his guests. The text also provides a picture of a God who offers the blessing through an act of anointing the singer of Ps 23. Interestingly, the Imago Dei that Ps 23 casts is one of a deity who is inseparable from the societal issues which the addressees of the Psalm experienced. Put differently, in Ps $23 \mathrm{YHWH}$ is not detached from society. Thus, the investigation of the Imago Dei in light of the societal issues that were probably experienced by the addressees of the Psalm, is warranted.

1 James H. Cone, The Cross and the Lynching Tree (Maryknoll, New York: Orbis Books, 2011), 160; cf. James H. Cone, 'Strange Fruit: The Cross and the Lynching Tree,' Harvard Divinity Bulletin 35/1 (2007): 52.

2 The tetragrammaton of four letters is the Hebrew theonym commonly transliterated into Latin letters as YHWH. It is one of the names of the national God of the Israelites used in the Hebrew Bible. 


\section{IMAGO DEI IN THE CONTEXT OF POVERTY}

Based on the interpretation of Ps 23 in light of other exilic and post-exilic texts, it seems that the addressees of the Psalm experienced poverty. The phrase 'be in need' in v. 1 provides a clue about the issue of poverty that the addressees of Ps 23 experienced. In the post-exilic literature the phrase 'be in need' is often used to portray a situation of being without food (cf. Ps 23:1; Eze 4:17; Jdg 19:19; Job 30:3). Ezekiel 4:17, one of the post-exilic texts, ${ }^{3}$ states that when: 'Lacking bread and water, they will look at one another in dismay, and waste away under their punishment.' No doubt, based on the preceding text, the issue of hunger - need for food - was a bone of contention in post-exilic Yehud. Furthermore, the phrase 'be in need' is employed in Judges 19:19 - a post-exilic text ${ }^{4}$ - in relation to the provision of bread. In this case, the author of the Book of Judges imagines a situation in which the experienced hunger will be alleviated. Furthermore, a post-exilic text, ${ }^{5}$ namely, Job 30:3 states that: 'through want and hard hunger they gnaw the dry and desolate ground.' Even in this case, the text mirrors a context in which the poor Jews experienced hunger.

Interestingly, the reality of poverty constitutes the social location of the singer of Ps 23 within which the Imago Dei is in turn presented. God is portrayed as the one who provides the poor with food. In Ps 23 God becomes an active participant in the attempt to alleviate the poverty of Jews in the post-exilic period. The statement: 'He makes me lie down in green pastures' (v.2) imagines a God who creates an environment in which the poor benefit from the wealth that accrues from the use of economic resources. In such an environment, the poor will no longer be in need. The phrases, 'He makes me lie' and 'He leads me' (v.2), particularly in the context of poverty, produce an image of a God who provides the leadership which prioritises the alleviation of poverty. The Imago Dei presented in Ps 23 is that of a God who is not only actively involved in the attempt to alleviate poverty, but who equally provides leadership which creates an environment in which the poor also benefit from the wealth created by the rich élites.

3 Christophe Nihan, 'The Memory of Ezekiel in Postmonarchic Yehud,' in Remembering Biblical Figures in the Late Persian and Early Hellenistic Periods: Social Memory and Imagination (ed. Diana V. Edelman, and Ehud Ben Zvi; Oxford: Oxford University Press, 2013), 415-417.

4 Cheryl J. Exum, 'Judges,' in Harper's Bible Commentary (ed. James L. Mays; San Francisco: Harper \& Row Publishers, 1988), 245-261; Madipoane Masenya (ngwan'a Mphahlele), 'Sacrificing Female Bodies at the Altar of Male Privilege: A Bosadi (Womanhood) Reading of Judges 19,' Journal of Theology and Religion in Africa 27/1 (2003): 100.

5 Harold H. Rowley, 'The Book of Job and its Meaning,' Bulletin of the John Rylands Library 41 (1958): 197; Norman C. Habel, The Book of Job: A Commentary (Philadelphia: Westminster Press, 1985), 40-42; John E. Hartley, The Book of Job (Grand Rapids, Michigan: Wm. B. Eerdmans Publishing, 1988), 17; Shmuel Vargon, 'The Date of Composition of the Book of Job in the Context of S.D. Luzzatto's Attitude to Biblical Criticism,' The Jewish Quarterly Review 91/3-4 (2001): 377 . 


\section{A GOD WHO IS AGAINST CORRUPTION}

The connection made by Old Testament scholars ${ }^{6}$ between Pss 24, 23 and 16 enables one to read Ps 23:3 as a text that exhibits a clue about the issue of corruption which was possibly experienced by the addressees of Ps 23 in post-exilic Yehud. Whilst Ps 16:10 reads: 'For you do not leave my soul at Sheol; neither do you let your Holy One see corruption', Ps 23:3 interestingly stipulates: 'He brings back my soul. He leads me in the paths of justice, for his name's sake.' These verses portray a God who is against corruption. In terms of the manner in which Pss 16:10 and 23:3 are written, the act of letting the Holy One not to see 'corruption' is synonymous to that of leading one to 'ethical ways'. ' Given the connection between the nouns 'corruption' and 'paths/ethical ways', it is reasonable to argue that the addressees of Ps 23 also experienced corruption which led the composer of the Psalm to mention that YHWH leads him or her in the 'paths/ethical ways' of justice. In this instance, not only is YHWH against corruption, He also leads one out of corruption.

What about the connection between Ps 23 and 24? The mention of 'clean hands', 'pure hearts', that which is 'false', and 'deceit' in Ps $24: 4$ points in the direction of corruption. Based on the modern definition of corruption as the abuse of public power for private benefit, that is, a deceitful use of a position of trust for dishonest gain, the view that Ps $24: 4$ suggests corruption is valid. ${ }^{8}$ Therefore, in Pss 24 and 23 God identifies with the principles of honesty and justice. ${ }^{9}$ These texts provide an image of a God who leads people towards an ethic which is typified with 'clean hands' and 'pure hearts'. The leadership of God in Ps 23 addresses the issue of corruption and subsequently leads people towards the ethical ways of justice.

\section{GOD AND INJUSTICES}

A closer look at Ps 23 enables an argument that the addressees of the singers of the Psalm experienced some form(s) of injustices, which necessitated the insertion of the noun 'tsedeq' which means 'justice' in v. $3 .^{10}$ Noteworthy, there appears to have been various forms of injustices in the late exilic and post-exilic period, which ranged from the exploitation of the poor through heavy taxation; to the creation of

6 Nancy L. DeClaissé-Walford, 'An Intertextual Reading of Psalms 22, 23, and 24,' in The Book of Psalms: Composition and Reception (ed. Peter W. Flint, and Patrick D. Miller Jr.; Leiden, Boston: Brill, 2005), 151; Alphonso Groenewald, 'Ethics of the Psalms: Psalm 16 within the Context of Psalms 15-24,' Journal for Semitics 18/2 (2009): 426, 428; Phil J. Botha, 'Answers Disguised as Questions: Rhetoric and Reasoning in Psalm 24,' Old Testament Essays 22/3 (2009): 536, 551.

7 DeClaissé-Walford, 'Intertextual Reading of Psalms,' 151; Groenewald, 'Ethics of the Psalms,' 428.

8 Vito Tanzi, 'Corruption around the World: Causes, Consequences, Scope, and Cures,' International Monetary Fund 45/4 (1998): 564.

9 Groenewald, 'Ethics of the Psalms,' 428.

10 See DeClaissé-Walford, 'Intertextual Reading of Psalms,' 150. 
the indebtedness of the poor; to the confiscation of the land owned by the poor; and to slavery. Thus, McNutt remarks:

\begin{abstract}
Regardless of who owned the majority of the land, the economic well-being of the local population in Persian-period Judah seems to have declined progressively over time, with the development of a high degree of poverty, particularly in rural areas, resulting in some cases in an inability to pay off debts, and consequently the necessity of selling off land to the more wealthy. This was likely caused in part by the Persian government's depletion of the rural economy through heavy taxation, and in part by the fact that the taxes had to support the local élites as well as the empire. ${ }^{11}$
\end{abstract}

Given the preceding remark, since Ps 23 does not explicitly mention various forms of injustices in the post-exilic period, the text of Nehemiah (which comes from the same period) sheds light on such injustices. For instance, Nehemiah 5:10-12 which confirms McNutt's view, is against the exploitation of the poor in terms of the system of heavy taxation, the issue of indebtedness, land use and slavery.

Therefore, if Ps 23:3 is advocating for justice in the post-exilic period, it makes sense to argue that the Imago Dei presented in Ps 23 is that of a God who protests the exploitation of the poor through heavy taxation; the creation of the indebtedness of the poor; the landlessness of poor; and the conditions of slavery. In Psalm $23 \mathrm{God}$ advocates for tsedeq - 'justice'.

\title{
GOD AND THE ISSUE OF CONFLICT IN THE POST- EXILIC COMMUNITY
}

As Zenger decisively argued, Ps 23 has its historical context or social location mostly in a situation of conflict, argumentation and attack. ${ }^{12}$ The adjective 'evil' (cf. v.4b) and the phrase, 'those who oppose me' (cf. v.5a) as well as the expression 'shadow of death' (cf. v.4a) support Zenger's position. It becomes certain then that based on the connection between vss. 4 and 5, the singers of the Psalm had a situation of hostility and conflict in mind when he or she composed Ps 23. Noteworthy, given the issue of classism, economic inequalities and the adverse treatment of the poor from the rural Yehud, McNutt's observation of the conflict between the returning exiles and those who remained in Yehud, namely the so-called 'people of the land' would also make sense. ${ }^{13}$

The Imago Dei portrayed in Ps 23 specifically in relation to the issue of conflict is interesting. In a situation of a conflict one would expect to discover a God who reconciles the persons in conflict. Instead, the Psalm portrays a God who is on the

11 Paula McNutt, Reconstructing the Society of Ancient Israel (Louisville, Kentucky: Westminster John Knox Press and London: SPCK, 1999), 196-197.

12 Erich Zenger, Die Nacht wird leuchten wie der Tag: Psalmenauslegungen (Freiburg: Herder, 1997), 219.

13 McNutt, Society of Ancient Israel, 200-202. 
side of those who are in a disadvantaged position. No doubt, YHWH identifies with those who are in need of comfort because Ps 23 portrays a deity who comforts the one who is being attacked by the enemies. The statement: 'Even though I walk through the darkest valley, I fear no evil; for you are with me; your rod and your staff - they comfort me' provides imagery of a God who is not only omnipresent, but who is also in solidarity with the person who is faced with perilous circumstances. On this point, God is with the persons who are confronted by the 'evil' of the enemies. Furthermore, in v.5, God is portrayed as a servant or a host who prepares a table for a person who is being attacked by his or her enemies.

The 'goodness and mercy' of YHWH referred to in the concluding verse of the Psalm (v.6) is expressed in the character and work of YHWH shown throughout the Psalm. Therefore, the 'goodness and mercy' of YHWH is expressed by the Imago Dei exhibited by Ps 23. Based on the discussion above, the text in question reveals a God who is not detached from society - particularly from the issues of poverty, corruption, injustices and conflicts. Thus, one wonders whether the idea of 'goodness and mercy' in Ps 23 would relate to John Wesley's theology on the 'works of mercy', and more vitally in the South African context.

'Goodness and mercy' meets John Wesley's 'works of mercy' and 'doing good'

In his contribution, 'The poor and the people called Methodists: An Exhibit,' Heitzenrater suggest that John Wesley's theology on the 'works of mercy' and on 'doing good' defines the character of the people called Methodist. ${ }^{14}$ For him, the 'works of mercy' include: 'teaching, feeding, and clothing poor children; furnishing gainful employment to the jobless; giving loans to struggling entrepreneurs; visiting the sick and the prisoners; providing food, money, clothing, shelter, books, medicine, and other essentials to the needy. ${ }^{15}$ Clearly, the 'works of mercy' should characterise active participation of Methodist people in service of humanity. Nyengele's observation that: 'works of mercy, as dimensions God's sanctifying grace, therefore, orient the church toward public engagement and social action, to address social ills and facilitate social transformation' adds a curious dimension to the understanding of

14 Richard P. Heitzenrater, 'The Poor and the People Called Methodists: An Exhibit,' in The Poor and the People Called Methodist, (ed. Richard P. Heitzenrater; Nashville: Abingdon Press, 2002), 211.

15 Richard P. Heitzenrater, 'The Imiatio Christi and the Great Commandment: Virtue and Obligation in Wesley's Ministry with the Poor,' in The Portion of the Poor (ed. Douglas Meeks; Nashville, Tennessee: Kingswood, 1994), 49. 
John Wesley's theology on the 'works of mercy'. ${ }^{16}$ Therefore, it is reasonable to submit that the latter theology calls the Methodist Church to be mission driven in terms of addressing the ills of many a society. Furthermore, as Nyengele excellently perceived, a Church inspired by John Wesley's theology on the 'works of mercy' is one which pursues justice for the marginalised, excluded and oppressed people in modern societies. ${ }^{17}$ On this point, one may ask: What is mercy? As Mtshiselwa describes: 'mercy is driven by the need to see the restoration of the dignity of God's image bearers to their initial created state. Based on the experience of restoration, human beings are enabled to take up their partnership with God in transforming society through mercy. ${ }^{18}$ Mtshiselwa's descriptive definition of mercy is as appealing as the image of a merciful God embedded in Ps 23, which is typified by the restoration of the dignity of human beings.

Significantly, the striking parallels between John Wesley's theology on 'works of mercy' and the expression of 'goodness and mercy' in Ps 23 are noticeable. Based on Heitzenrater's assertion that the 'works of mercy' comprise the provision of food and employment to the poor, among other services, it may therefore be deduced that the 'works of mercy' are an attempt to alleviate poverty. That Ps 23 seeks to alleviate the poverty of the addressees enables a striking parallel between John Wesley's theology on 'works of mercy' and the expression of 'goodness and mercy' in Ps 23. Ps 23 presents a God who is actively involved in the pursuit to alleviate poverty of the Jews in post-exilic Yehud. If human beings are to be co-partners with God, then the adoption of the role of addressing poverty as provisioned by John Wesley's theology on 'works of mercy' is an appealing step towards the provision of 'goodness and mercy' to the poor. Furthermore, as aforementioned, Mtshiselwa's view that mercy is driven by the need to restore the dignity of human beings, relates to the image of a God who restores the soul of a human being. ${ }^{19}$ Based on the preceding view, there is a clear parallel between Ps 23 and John Wesley's theology on 'works of mercy'. The consideration of the prisoner in John Wesley's theology on the 'works of mercy' draws to mind the imagery of a deity who leads people towards the ethical ways of justice. However, this connection is not so clear. But, if the ministry to the prisoners is viewed as an attempt to lead the convicted person towards an ethical way of living, then it may be reasonable to draw parallels between John Wesley's theology on the 'works of mercy' and the image of a God who leads people to ethical ways in Ps 23. Since the text under consideration alludes to both the goodness and mercy of YHWH, it is therefore pertinent to also give attention to the dimension of goodness.

16 Fulgence Nyengele, 'African Spirituality and the Wesleyan Spirit: Implications for Spiritual Formation in a Multicultural Church and Culturally Pluralistic World,' (Paper read the Practical Theology section of the Oxford Institute of Methodist Theological Studies, Oxford, England, 2013), 18.

17 Nyengele, 'African Spirituality,' 18.

18 Pumla Mtshiselwa, Interview with Pumla Mtshiselwa on Mercy. Audio, August 14, 2015.

19 Mtshiselwa, Interview with Pumla. 
The idea of 'doing good' finds its expression in Wesley's statement on the character of a Methodist. He says:

Lastly, as he has time, he "does good unto all men" - unto neighbours, and strangers, friends, and enemies. And that in every possible kind; not only to their bodies, by "feeding the hungry, clothing the naked, visiting those that are sick or in prison," but much more does he labour to do good to their souls, as of the ability which God giveth... ${ }^{20}$

This statement shows that the idea of 'doing good' bears with the theology on the 'works of mercy' based on the reference to the practice of feeding the hungry, among other issues, and subsequently enabling the appreciation of the link between the concepts of 'goodness' and 'mercy' in Ps 23. On the issue of 'doing good', Benefiel's remark comes to mind:

It is the character of the people of God to engage the world in mission in a similar way that God has displayed in Christ Jesus, that is to say, incarnationally. Rather than moving away from the sin, pain and suffering of the world, the character of holiness in the people of God inclines them to move right into the midst of such a world. ${ }^{21}$

In relation to YHWH's 'goodness and mercy', the preceding remark bears a striking similarity with the Imago Dei which is presented by the singer of Ps 23. That this Psalm shows a God who is not distant from the suffering of the Jews produces a parallel between Ps 23 and the John Wesley's theology on 'doing good', mainly because Wesley views the Methodist people as called to comfort the people who are suffering. On this point, Wesley has this to say:

The only true religion in the sight of God is this, to visit with counsel, comfort, and relief, the fatherless and widows - Those who need it most, in their affliction - In their most helpless and hopeless state; and to keep himself unspotted from the world - From the maxims, tempers, and customs of it. ${ }^{22}$

In this case, Wesley shows that the provision of comfort and relief to the needy persons sheds light on the meaning of 'doing good'. Thus, the addressees of Ps 23 would identify with the theology on 'doing good' as they too experienced the comfort of YHWH in their helpless and hopeless situation. In addition, based on the duties of the deaconesses, it becomes clear that: 1) being in solidarity with the persons who are in a disadvantaged position; 2) comforting the sorrowing; 3 ) being actively involved in a ministry of alleviating poverty; and 4) saving the sinful persons, will

20 John Wesley, 'The Character of a Methodist' (1742), in The Methodist Societies: History, Nature, and Design, ed. Rupert E. Davies, vol. 9, The Works of John Wesley (Nashville: Abingdon, 1989), 37.

21 Ron Benefiel, 'Christian Holiness and the Wesleyan Mission of Mercy: The Character of the People of God in the World,' in Holiness as a Root of Morality: Essays on Wesleyan Ethics: Essays in Honor of Lane A. Scott (ed. John S. Park; Wales: Edwin Mellen Press, 2006), 137. 
express the implications of 'doing good'. ${ }^{23}$ The latter implication resonates with YHWH's 'goodness and mercy' which is articulated in Ps 23.

Noteworthy is the fact that both the theology on 'works of mercy' and on 'doing good' do not explicitly mention the issue of corruption. However, it must be said that mercy cannot exist on the same platform as corruption. That is, the presence of corruption inevitably implies the lack of mercy, whilst the presence of mercy presupposes the absence of corruption. Thus, the reference to the issue of corruption adds a curious dimension to Wesley's concept of sin. In his sermon, 'Causes of the Inefficacy of Christianity' Wesley perceives salvation as a remedy to the corruption of the human nature of the Methodist people. ${ }^{24}$ Furthermore, Wesley presents a comparison between the image of God and the image of a fallen Adam. In this comparison, he states that the image of God includes an aspect of 'righteousness' and 'immortality', whilst the image of a fallen Adam includes a feature of 'corruption' and 'death'. ${ }^{25}$ Of significance here is the observation that the restoration of the soul from Sheol towards being lead to the ethical ways or paths of righteousness in Ps 23:3, may be viewed as synonymous to the redemption of the fallen Adam from 'corruption' and 'death'. It also becomes clear that the idea of saving the sinful persons (which alludes to the concept of 'doing good') refers to the redemption of human beings from their corruption. Thus, it is reasonable to deduce that John Wesley's theology on 'doing good' resonates with the picture of a God who is against corruption in Ps 23.

Given the comparison of 'goodness and mercy' with John Wesley's theology on the 'works of mercy' and on 'doing good', it is becomes clear that based on the parallels drawn here, Ps 23 would enjoy a positive reception among the people called Methodist. However, lest we remain irrelevant to the modern context from which Ps 23 is read today, a pertinent question to ask is: What do we make of the parallels between the idea of 'goodness and mercy' (cf. Ps 23:6) and John Wesley's theology on the 'works of mercy' and 'doing good' in South Africa today?

\section{IMPLICATIONS OF 'GOODNESS AND MERCY' FOR THE METHODIST PEOPLE IN SOUTH AFRICA TODAY}

As mentioned earlier, human beings are co-partners with God in the plan of salvation, thus the proposal made here is that the Methodist people may be inspired by the image of a God who provides 'goodness and mercy'. Put differently, in light of the MCSA, the mission strategies of the Methodist people validate an idea of 'goodness and

23 Laceye Warner, 'Towards a Wesleyan Evangelism,' Methodist History 40/4 (2002): 239.

24 John Wesley, 'Causes of the Inefficacy of Christianity,' n.p. 1879. http://wesley.nnu.edu/johnwesley/the-sermons-of-john-wesley-1872-edition/sermon-116-causes-of-the-inefficacy-ofchristianity/ (accessed 17 August 2015).

25

Wesley, 'Causes of the Inefficacy,' n.p. 
mercy' (cf. Ps 23:6) which is certainly reflected in John Wesley's theology on 'works of mercy' and 'good works'. However, it must be admitted that it is not necessary for the Methodist people to re-invent a new model for 'doing good' and upholding the 'works of mercy', because the MCSA already has 'a mission consciousness shaped by the imperatives of spirituality, evangelism and church growth, justice and service, development and economic empowerment', ${ }^{26}$ and education. Interestingly, though, when enthused by Ps 23, poverty, corruption, injustice and conflict could be viewed as areas that need immediate attention in post-apartheid South Africa. Thus, it is critical for the Methodist people to align the mission imperatives of the MCSA to the preceding areas.

The issue of poverty is articulated in the imperative of development and economic empowerment. As mentioned earlier, the 'works of mercy' include: 'teaching, feeding, and clothing poor children' and most importantly 'furnishing gainful employment to the jobless; giving loans to struggling entrepreneurs'. Thus, on the issue of 'goodness and mercy' (cf. Ps 23:6) which follows the poor, it would make sense for the poor in South Africa to be the recipients of the 'works of mercy' that are in a form of employment or a loan to establish businesses, among other practical endeavours. The implication made here is this: enthused by Ps 23 and John Wesley's theology on the 'works of mercy', the imperative of development and economic empowerment calls for the Methodist to share information about companies that are recruiting employees in order to contribute to job creation. In the same vein, the preceding imperative calls Methodist people to share with the poor information about the availability of bursaries for students excelling in their studies. Sharing such information might alleviate poverty in the communities that are experiencing this challenge.

Regarding the issue of corruption that is evident in the South African context as well as the post-exilic Yehud community, the imperative of spirituality could offer transformative possibilities. As mentioned above, Wesley correctly argued that the salvation which is attained from Christ addresses the corruption of our human nature. On this point, not only can corruption be addressed through our legal systems, but it can equally be addressed through the efforts of deepening the spirituality of Methodist congregants as well as of the society. The deepening of spirituality would subsequently regenerate the moral fibre of South Africans because of the biblical fact that a relationship with God challenges one to live according to the principles of God. For instance, the Hebrew Bible demands of modern readers to live in accordance with the 10 commandments which prohibit one from stealing or corruption. Therefore, most certainly, a process of deepening the spirituality of

26 Dion Forster, 'Prophetic Witness and Social Action as Holiness in the Methodist Church of Southern Africa's Mission,' Studia Historiae Ecclesiasticae 34/1 (2008): 427-428. Cf. See MCSA, 2006 Yearbook of the Methodist Church of Southern Africa (Cape Town: Methodist Publishing house, 2006), 3-22. 
South Africans could offer helpful possibilities in the attempts at addressing the issue of corruption. On the issue of corruption in South Africa, although Vorster does not explicitly refer to mission imperatives of the MCSA, he makes a valid point:

We are disturbed that the trajectory of corruption started under apartheid continues from top leadership in business, politics, to the traffic police, shop, sales-person teller etc, and no one seems to do anything about this. It seems that the axiom is: "If everyone is doing it then it must be okay." Or "That's just the way the world is..." 27

Not only does this statement provide evidence that the MCSA has attempted to engage the issue of corruption, it also demands of Methodist people to articulate the impact of corruption to the poor in South Africa. This demand resonates with the rejection of corruption in the context of Ps 23 and in John Wesley's theology of salvation from the sin of corruption.

The imperative of justice and service is set to address the issues of injustices in South Africa. The investigation of the possible context from which Ps 23 emerged has revealed that there were various forms of injustices in the late exilic and post-exilic period, which ranged from the exploitation of the poor through heavy taxation; to the creation of the indebtedness of the poor; to the confiscation of the land owned by the poor; and to slavery. South Africans may identify with these forms of injustices. Interestingly, one wonders whether the protest by the working-class people against the e-toll system in Gauteng does not resonate with the heavy taxation of the Jews in the late exilic and post-exilic period ${ }^{28}$ Although the Jews did not protest against e-tolls per se in post-exilic Yehud, there were concerns about the heavy taxation system which the working-class people in South Africa could identify with. Some South Africans are concerned about being subjected to the payment of an additional tax which is through the e-toll system. Furthermore, black people are presently being given productive land without the sufficient capital and skills and as a result they fail to work the land..$^{29}$ On this issue of land, the argument would hold that the confiscation of the land given to the poor without skills and the capital to work the land reminds one of the confiscation of the land of the poor Jews in the post-exilic period. With respect to the issue of slavery, Masenya (ngwan'a Mphahlele) decisively argues that some of the protesting miners - the so-called working-class 'slaves' in Marikana are 'stuck in the perpetual cycle of poverty which was inherited from the inequities

27 Mike Vorster, 'Natal Coastal District (07),' in 2015 Yearbook of the Methodist Church of Southern Africa (ed. MCSA; Cape Town, Methodist Publishing House, 2015), 51.

28 Glynnis Underhill, 'DA begins e-toll court challenge,' n.p. http://mg.co.za/article/2014-03-04-dabegins-e-toll-court-challenge, (accessed 14 August 2015).

29 Ndikho Mtshiselwa, 'Re-reading the Israelite Jubilee in Leviticus 25:8-55 in the context of land redistribution and socio-economic justice in South Africa: An African Liberationist perspective,' (Unpublished thesis, University of South Africa, Department of Biblical and Ancient Studies, 2015), 124. 
of the apartheid era'.$^{30}$ Not only is this view confirmed by the persistent protest of the working-class people, it equally shows the need for justice in South Africa. Thus, the imperative on justice and service is critical in attempts to address issues of injustice raised in the context of the mining sector. It must be noted with appreciation that the Methodist clergy 'exercised a ministry of presence, care and peace-making where there was real potential for further conflict' at Marikana. ${ }^{31}$ The imperative of justice and service calls Methodist people to be active participants in the discourse and struggle of the working-class people against the injustices often experienced by the protesting miners, as well as modern forms of heavy taxation, indebtedness of the poor, and landlessness of many a black person.

South Africa has witnessed various conflicts, of which one is the so-called xenophobic attacks. Disturbing to note is the widespread looting of migrant shops and xenophobic attacks against foreign nationals throughout South Africa in 2015. ${ }^{32}$ The attack on the psalmist that is reflected in the text under investigation and the conflict between the Jews and foreign nationals in post-exilic Yehud, relate to the xenophobic attacks against foreign nationals in South Africa. Based on both Ps 23 and John Wesley's theology on 'works of mercy' and on 'good works', as well as on the mission imperatives of the MCSA, the significance of the imperative on education lies with this point: teaching pupils the history of black people in South Africa at the level of basic education is critical. History would shed light on how many black people migrate to various countries and receive each other with love that is fused on the ethic of Ubuntu. This ethic reminds one of Motho ke motho ka batho, which means, 'I am because we are', or 'we are because I am.' Education initiatives are not foreign to Methodist people in South Africa. Under the leadership of the former Bishop, the Reverend Losaba, the Methodist people of the Ngqushwa municipality established an education Sunday which showcased excellence in education on the part of the learners and teachers. This also offered educative support to the parents and learners. ${ }^{33}$ The initiative provides a model which may be adopted to offer teaching on the history of immigration in Africa in order to address the attacks of the foreign nationals in the country. Furthermore, with respect to education and concrete examples of how the MCSA is currently implementing its works of 'justice and mercy', the training of seminarians at Seth Mokitimi Methodist Seminary (SMMS) comes to mind. That the MCSA is forming leaders who will in turn be catalysts

30 Madipoane Masenya (ngwan'a Mphahlele), 'Eating the Louse and its Larva! The Indignity of Poverty as Embedded within Selected African and Old Testament Proverbs,' Scriptura 111/3 (2012): 453.

31 Themba Mntambo, 'Limpopo District (11)' in 2015 Yearbook of the Methodist Church of Southern Africa, (ed. MCSA; Cape Town: Methodist Publishing House, 2015), 69.

32 Heribert Adam, Kogila Moodley, 'Mob violence sets SA xenophobia apart,' n.p. http://mg.co.za/ article/2015-05-06-violence-sets-sa-xenophobia-apart (accessed 17 August 2015).

33 Musi SJ. Losaba, 'Grahamstown District (02),' in 2015 Yearbook of the Methodist Church of Southern Africa, (ed. MCSA; Cape Town: Methodist Publishing House, 2015), 37. 
of transformation in South Africa, as Kumalo and Richardson observed, presents the 'works of mercy' on the part of the church which needs to be supported by all Methodist people. ${ }^{34}$

Clearly, given the parallels between Ps 23 and the South African context, it is reasonable to deduce that the Psalm would be relevant in South Africa. The reading of this Psalm in conversation with John Wesley's theology on the 'works of mercy' and 'doing good' supports the argument made here that the idea of 'goodness and mercy' in Ps 23 resonates with the mission imperatives of the MCSA. Thus, implications of Ps 23 and John Wesley's theology on the 'works of mercy' and 'doing good' for the Methodist people in South Africa today, are convincing.

\section{CONCLUSION}

Put succinctly, the Imago Dei that is observed in Ps 23 is as follows:

- Not only is God active and involved in the pursuit to alleviate poverty, but equally provides leadership that creates an environment in which the poor also benefit from economic resources.

- The leadership of God in Ps 23 addresses the issue of corruption and leads people towards ethical ways of justice.

- God protests the exploitation of the poor through heavy taxation; the creation of the indebtedness of the poor; the landlessness of the poor; and the conditions of slavery.

- God is on the side of those who are in a disadvantaged position. This God is with those persons who are confronted by the 'evil' of the enemies. In other words, he is on the side of those who are attacked by the enemies.

The preceding image of God was subsequently related to John Wesley's theology on the 'works of mercy' and on 'doing good' and more importantly in light of the mission imperatives of the MCSA within the post-apartheid South African context? Thus, I submit that the Methodist people in South Africa today need to be the interlocutors of 'goodness and mercy'.

\section{LIST OF REFERENCES}

Adam, Heribert and Moodley, Kogila. 'Mob violence sets SA xenophobia apart.' n.p. http://mg.co. za/article/2015-05-06-violence-sets-sa-xenophobia-apart (accessed 17 August 2015).

34 Simanga Kumalo and Neville Richardson, 'Seth Mokitimi and Education for Ministry: What's in a Name?' Missionalia 38/2 (2010): 272. 
Benefiel, Ron. 'Christian Holiness and the Wesleyan Mission of Mercy: The Character of the People of God in the World.' Pages 125-150 in Holiness as a Root of Morality: Essays on Wesleyan Ethics: Essays in Honor of Lane A. Scott. Edited by John S. Park, Wales: Edwin Mellen Press, 2006.

Botha, Phil J. 'Answers Disguised as Questions: Rhetoric and Reasoning in Psalm 24.' Old Testament Essays 22/3 (2009): 535-553.

Cone, James H. 'Strange Fruit: The Cross and the Lynching Tree.' Harvard Divinity Bulletin 35/1 (2007): 46-55.

Cone, James H. The Cross and the Lynching Tree. Maryknoll, New York: Orbis Books, 2011.

DeClaissé-Walford, Nancy L. 'An Intertextual Reading of Psalms 22, 23, and 24.' Pages 139-152 in The Book of Psalms: Composition and Reception. Edited by Peter W. Flint and Patrick D. Miller Jr. Leiden, Boston: Brill, 2005.

Exum, Cheryl J. 'Judges.' Pages 245-261 in Harper's Bible Commentary. Edited by James L. Mays. San Francisco: Harper \& Row Publishers, 1988.

Forster, Dion. 'Prophetic Witness and Social Action as Holiness in the Methodist Church of Southern Africa's Mission,' Studia Historiae Ecclesiasticae 34/1 (2008): 411-434.

Groenewald, Alphonso. 'Ethics of the Psalms: Psalm 16 within the Context of Psalms 15-24.' Journal for Semitics 18/2 (2009): 421-433.

Habel, Norman C. The Book of Job: A Commentary (Philadelphia: Westminster Press, 1985), 40-42.

Hartley, John E. The Book of Job. Grand Rapids, Michigan: Wm. B. Eerdmans Publishing, 1988.

Heitzenrater Richard P. 'The Imiatio Christi and the Great Commandment: Virtue and Obligation in Wesley's Ministry with the Poor,' in The Portion of the Poor (ed. Douglas Meeks; Nashville, Tennessee: Kingswood, 1994), 49.

Heitzenrater Richard P. 'The Poor and the People Called Methodists: An Exhibit,' in The Poor and the People Called Methodist, (ed. Richard P. Heitzenrater; Nashville: Abingdon Press, 2002), 211.

Kumalo, Simanga and Richardson, Neville. 'Seth Mokitimi and Education for Ministry: What's in a Name?' Missionalia 38/2 (2010): 259-274.

Losaba, Musi S.J. 'Grahamstown District (02),' Pages 36-39 in 2015 Yearbook of the Methodist Church of Southern Africa. Edited by MCSA. Cape Town: Methodist Publishing House, 2015.

Masenya (ngwan'a Mphahlele), Madipoane. 'Sacrificing Female Bodies at the Altar of Male Privilege: A Bosadi (Womanhood) Reading of Judges 19.' Journal of Theology and Religion in Africa 27/1 (2003): 98-122.

Masenya (ngwan'a Mphahlele), Madipoane. 'Eating the Louse and its Larva! The Indignity of Poverty as Embedded within Selected African and Old Testament Proverbs.' Scriptura 111/3 (2012): 452-459.

MCSA, 2006 Yearbook of the Methodist Church of Southern Africa (Cape Town: Methodist Publishing house, 2006), 3-22.

Mntambo, Themba. 'Limpopo District (11).' Pages 68-72 in 2015 Yearbook of the Methodist Church of Southern Africa. Edited by MCSA. Cape Town: Methodist Publishing House, 2015. 
Mtshiselwa, Ndikho. 'Re-reading the Israelite Jubilee in Leviticus 25:8-55 in the context of land redistribution and socio-economic justice in South Africa: An African Liberationist perspective.' Unpublished thesis, University of South Africa, Department of Biblical and Ancient Studies, 2015.

Mtshiselwa, Pumla. 'What is Mercy?' Interview with Pumla Mtshiselwa on Mercy. Audio, August 14, 2015.

McNutt, Paula. Reconstructing the Society of Ancient Israel. Louisville, Kentucky: Westminster John Knox Press and London: SPCK, 1999.

Nihan, Christophe. 'The Memory of Ezekiel in Postmonarchic Yehud.' Pages 415-450 in Remembering Biblical Figures in the Late Persian and Early Hellenistic Periods: Social Memory and Imagination. Edited by Diana V. Edelman and Ehud Ben Zvi. Oxford: Oxford University Press, 2013.

Nyengele, Fulgence. 'African Spirituality and the Wesleyan Spirit: Implications for Spiritual Formation in a Multicultural Church and Culturally Pluralistic World.' Paper read the Practical Theology section of the Oxford Institute of Methodist Theological Studies, Oxford, England, 2013.

Rowley, Harold H. 'The Book of Job and Its Meaning.' Bulletin of the John Rylands Library 41 (1958): 167-207.

Tanzi, Vito. 'Corruption around the World: Causes, Consequences, Scope, and Cures.' International Monetary Fund 45/4 (1998): 559-594.

Underhill, Glynnis. 'DA begins e-toll court challenge.' n.p. http://mg.co.za/article/2014-03-04-dabegins-e-toll-court-challenge (accessed 14 August 2015).

Vargon, Shmuel. 'The Date of Composition of the book of Job in the Context of S.D. Luzzatto's Attitude to Biblical Criticism.' The Jewish Quarterly Review 91/3-4 (2001): 377-394.

Vorster, Mike. 'Natal Coastal District (07).' Pages 49-55 in 2015 Yearbook of the Methodist Church of Southern Africa. Edited by MCSA. Cape Town: Methodist Publishing House, 2015.

Warner, Laceye. 'Towards a Wesleyan Evangelism,' Methodist History 40/4 (2002): 230-245.

Wesley, John. 'The Character of a Methodist' (1742), Pages 35-41 in The Methodist Societies: History, Nature, and Design. Edited by Rupert E. Davies, vol. 9, The Works of John Wesley. Nashville: Abingdon, 1989,

Wesley, John. Explanatory Notes Upon the New Testament, London: Epworth, 1950.

Wesley, John. 'Causes of the Inefficacy of Christianity.' n.p. http://wesley.nnu.edu/john-wesley/ the-sermons-of-john-wesley-1872edition/sermo n-116-causes-of-the-inefficacy-ofchristianity/, 1879 (accessed 17 August 2015).

Zenger, Erich. Die Nacht wird leuchten wie der Tag: Psalmenauslegungen. Freiburg: Herder, 1997. 